\title{
ANALISIS IMPLEMENTASI APLIKASI SISTEM INFORMASI MANAJEMEN DAERAH (SIMDA) DI PEMERINTAH KABUPATEN SARMI
}

\author{
Dastrianti Syarifuddin
}

dastrianti0711@gmail.com

\begin{abstract}
This study examines the influence of Summit Management Support and Quality of Data on the Information Systems of the Sarmi's District. The population of this research is an employee of the local government. Testing initiated on the sample of 71 respondents. We selected the data from the community using purposive sampling. Data gathering collected with the direct survey. To test our hypotheses, we employed multiple regression. The research results prove that partially proven a low - affection rate affects a positive effect against the implant information on the regional board of the region. The summon management support has a positive impact on the implant to the region information on the government's local authority. Research results also discovered that the quality of the effects is a positively influential impact against the regionals information of region management registered on the government's regional authority. Research results suggesting that a level of users, uh, peaceful management support and quality of essential influences and significant significance of implementation of the local board of region management registered in the regional, regional registry of the district geographical region of Sarmi (Y).
\end{abstract}

Keywords: summit management support, data quality, Information systems.

\section{PENDAHULUAN}

Semenjak diberlakukannya kebijakan Otonomi Daerah di Indonesia, setiap Pemerintah Daerah berperan penuh dalam mengatur pemerintahannya sendiri. Kewenangan

Pemerintah Daerah dalam menjalankan pemberian Otonomi Daerah tersebut didukung dengan dikeluarkannya Undang-Undang Nomor 23 Tahun 2014 tentang Pemerintahan Daerah. Pemberian kewenangan kepada Daerah berupa Otonomi Daerah menjadikan daerah tersebut memiliki kewenangan dalam melakukan penyusunan dan perencanaan pembangunan yang sesuai dengan kebutuhan daerah. Penyusunan dan perencanaan pembangunan yang dimaksud termasuk pengelolaan anggaran/keuangan daerah. Sehingga dengan adanya otonomi daerah dan reformasi birokrasi, menimbulkan perubahan yang mendasar dalam manajemen keuangan daerah dimulai dari proses penganggaran, penatausahaan hingga pertanggungjawaban. 
Dalam rangka menciptakan tata kelola pemerintahan yang baik (good governace), maka perubahan paradigma tersebut perlu untuk dilakukan. Pelaksanaan prinsip tersebut mewajibkan Pemerintah Daerah untuk melaksanakan dan mempertanggungjawabkan pengelolaan keuangan daerah secara transparan, efisien, efektif dan akuntabel. Good governance dan clean government merupakan cita-cita dan harapan besar yang ingin dicapai oleh Pemerintah Daerah dalam penyelenggaraan Otonomi Daerah yang telah diberikan Pemerintah Pusat kepada setiap Daerah.

Dalam mewujudkan terciptanya good governance dan clean government, pemerintah daerah memerlukan sebuah sistem yang dapat diandalkan, dimana sistem tersebut mampu mendapatkan dan mengolah data untuk menghasilkan informasi yang digunakan oleh pemerintah daerah sebagai rujukan untuk mengambil keputusan terkait perencanaan dan pelaksanaan pembangunan daerah. Informasi-informasi yang dimaksud seperti laporan keuangan dan informasi keuangan lainnya secara lebih komprehensif, informasi terkait posisi keuangan daerah, kondisi kinerja keuangan, dan akuntabilitas pemerintah daerah.

Upaya pengelolaan ataupun manajemen daerah demi mewujudkan terselenggaranya good governance telah dikembangkan dalam sebuah sistem e-government dimana sistem ini telah dirumuskan dalam Inpres Nomor 3 Tahun, 2003 yaitu Pemerintah Daerah selaku pengguna ataupun pengelola dana publik diwajibkan agar mampu menyediakan sebuah informasi keuangan daerah yang dibutuhkan dengan akurat, relevan, tepat waktu, dan dapat dipercaya. Sehingga Pemerintah Daerah dituntut dan diwajibkan untuk memiliki serta menggunakan sebuah sistem informasi yang handal dan dapat mendukung Pemerintah Daerah dalam mewujudkan good governance dan clean government.

Salah satu tujuan diimplementasikannya e-Government untuk membantu peningkatan mutu pelayanan publik melalui pemanfaatan teknologi informasi sebagai proses penyelenggaraan pemerintah, menciptakan pemerintahan yang bersih, menciptakan 
transparansi, mampu menjawab berbagai tuntutan perubahan secara efektif, perbaikan organisasi, sistem manajemen yang baik, dan proses kerja kepemerintahan yang efisien dan efektif (Irawan, 2017). Oleh karena itu, mengacu pada Peraturan Pemerintah Nomor 56 Tahun, 2005 Tentang Sistem Informasi Keuangan Daerah, maka diterapkan sebuah teknologi informasi dengan menggunakan kecanggihan dari aplikasi teknologi komputer sebagai salah satu alat pendukung dalam sebuah proses sistem manajemen daerah. Hingga saat ini setiap pemerintah Kota/Kabupaten di Indonesia direkomendasikan untuk kiranya dapat mengimplementasikan sistem informasi manajemen daerah ataupun keuangan daerah berbasis aplikasi teknologi komputer.

Badan Pengawasan Keuangan dan Pembangunan (BPKP, 2020) melalui Pengawasan Bidang Penyelenggaraan Keuangan Daerah telah mengembangkan pemanfaatan teknologi dan informasi dengan menghadirkan sebuah sistem aplikasi yang dapat membantu setiap Pemerintah Daerah. Sistem aplikasi yang dikembangkan dikenal dengan nama Sistem Informasi dan Manajemen Daerah (SIMDA). SIMDA merupakan aplikasi bagian dari komponen Sistem Akuntansi Pemerintah Daerah (SAPD) yang disediakan untuk membantu Pemerintah Daerah melakukan sistem akuntansi, mulai dari penyelenggaraan hinga pertanggungjawaban pengelolaan keuangan daerah (Wibisono, 2017).

Salah satu tujuan utama pengembangan aplikasi SIMDA adalah untuk menghasilkan informasi yang lengkap, akurat dan akuntabel serta mengikuti Sistem Akuntansi Pemerintahan (SAP), maka tujuan penting dari pengembangan program aplikasi SIMDA tersebut antara lain (Dewi \& Senggarang, 2014): (1) Menyediakan database tentang kondisi di daerah secara terintegrasi; (2) Menghasilkan informasi penyelenggaraan Pemerintahan Daerah yang lengkap, tepat dan akurat yang dapat digunakan sebagai acuan pengambilan keputusan; (3) Menyiapkan perangkat daerah yang mampu menguasai dan memanfaatkan teknologi informasi; dan (4) Penguatan landasan Pemerintah Daerah dalam penyelenggaraan Otonomi Daerah. 
Guna mendukung suksesnya implementasi Sistem Informasi Manajemen Daerah (SIMDA), maka Deputi Pengawasan Bidang Penyelenggaraan Keuangan Daerah telah membentuk Satgas Pengembangan Sistem Informasi Manajemen Daerah, yang memiliki tugas: 1) mengembangkan dan melakukan pemutakhiran terhadap program aplikasi SIMDA yang berkaitan dengan pembangunan/peningkatan kapasitas pemerintah; 2) memberikan bimbingan teknis kepada Satgas SIMDA Perwakilan BPKP yang ditugaskan dalam asistensi; dan 3) membantu Satgas SIMDA Perwakilan BPKP melakukan asistensi implementasi program aplikasi SIMDA pada Pemerintah Daerah (Wibisono, 2017). Sampai dengan tahun 2017 sudah ada empat macam SIMDA yang dikembangkan oleh BPKP dan diimplementasikan oleh Kabupaten/Kota, seperti 1) SIMDA Keuangan; 2) SIMDA Barang Milik Daerah; 3) SIMDA Gaji; dan 4) SIMDA Pendapatan. Kemudian ada juga SIMDA Perencanaan, yang baru dikembangkan dan digunakan pada tahun 2018.

Saat ini setiap Pemerintah Daerah Kabupaten/Kota termasuk pemerintah Kabupaten Sarmi dituntut agar mampu menyusun Laporan Pertanggungjawaban secara akuntabilitas dan transparan. Sehingga diharapkan dengan adanya pengembangan dari aplikasi SIMDA yang disertai dengan kualitas Sumber Daya Manusia yang baik di Pemerintah Daerah Kabupaten/Kota, akan mampu mengukur kinerjanya sendiri dengan lebih optimal.

Merujuk dari beberapa peraturan-peraturan yang terkait dengan pengelolaan Keuangan Daerah, saat ini Pemerintah Kabupaten Sarmi sedang berupaya keras dalam menyediakan sistem informasi dan manajemen daerah berbasis aplikasi SIMDA. Upaya ini dilakukan dengan tujuan untuk menciptakan sistem pengelolaan Keuangan Daerah yang bersih, akuntable, transparan, efektif, dan efisien. Selain itu tujuan lain dari diterapkannya sistem informasi dan manajemen daerah berbasis aplikasi SIMDA yaitu untuk mengetahui sejauh mana perkembangan pembenahan tata kelola yang dilakukan oleh pemerintah Kabupaten Sarmi. Kemudian rencana lain dari mengimplementasikan aplikasi SIMDA di Kabupaten Sarmi yaitu sebagai langkah dalam pencegahan korupsi yang teritergrasi 
berbasis elektronik dengan penerapan e-Planning dan e-Budgeting. Hal ini penting guna meningkatkan kualitas Laporan Keuangan pemerintah daerah menuju terwujudnya good governance.

Pemerintah Daerah Kabupaten Sarmi mulai menggunakan aplikasi SIMDA sejak awal tahun 2017 hingga saat ini. SIMDA yang digunakan adalah SIMDA Keuangan dan SIMDA gaji. Namun, keterbatasan Informasi Teknologi (IT) dan Sumber Daya Manusia (SDM) menjadi salah satu penghambat dalam Implementasi Aplikasi SIMDA di lingkungan Pemerintah Kabupaten Sarmi. Sehingga, dengan melihat keadaan ataupun kondisi yang telah diuraikan diatas, maka dalam penelitian bertujuan untuk menganalisis tentang Implementasi Aplikasi SIMDA di Pemerintah Kabupaten Sarmi.

\section{LANDASAN TEORI DAN PENGEMBANGAN HIPOTESIS}

\section{Technology Acceptance Model (TAM)}

Technology Acceptance Model (TAM) merupakan model penerapan teknologi yang mengadopsi Theory of Reasoned Action (TRA) dari Fishbein \& Ajzen (1975) yang digunakan untuk melihat tingkat penggunaan responden dalam menerima teknologi informasi. TRA ini tersusun dari asumsi dasar bahwa setiap manusia berperilaku dengan sadar dalam mengendalikan diri dan mempertimbangkan penggunaan informasi yang tersedia untuk digunakan dalam kehidupannya. Fishbein \& Ajzen (1975) menyatakan seseorang yang berniat melakukan perbuatan tertentu dapat dipengaruhi oleh dua faktor tertentu, pengaruh pertama berhubungan dengan sikap (attitude towards behavior) dan pengaruh yang selanjutnya adalah pengaruh sosial yaitu norma subjektif (subjective norms).

Dengan dasar teori yang kuat melalui adopsi Theory of Reasoned Action (TRA), Davis (1986) mengembangkan Model Technology Acceptance Model (TAM). Technology Acceptance Model menggunakan pendekatan teori perilaku (behavioral theory) yang banyak digunakan untuk mengkaji proses adopsi teknologi informasi. (Davis, 1986; Fatmawati, 2015; Handayani, Kusrini, \& Arief, 2017) menyatakan konsep Technology Acceptance Model 
(TAM) merupakan sebuah teori yang menawarkan landasan untuk mempelajari dan memahami perilaku pemakai teknologi dalam menerima dan menggunakan teknologi yang ditawarkan. Kelebihan Technology Acceptance Model yaitu sederhana namun tetap valid, dimana menjelaskan secara sederhana hubungan sebab akibat antara perilaku dan keyakinan, tujuan, serta penggunaan actual dari pengguna system informasi (Noviarni, 2014).

\section{Stewardship Theory}

Donaldson \& Davis (1989) menggambarkan Stewardship Theory sebagai suatu situasi dimana manajemen tidak termotivasi oleh tujuan individu, tetapi lebih ditujukan pada tujuan hasil utama mereka untuk kepentingan organisasi. Dalam teori ini diasumsikan bahwa ada hubungan yang kuat antara kepuasan dan kesuksesan organisasi.

\section{Keuangan Daerah}

Dalam Peraturan Pemerintah Nomor 58 Tahun, 2005 disebutkan bahwa keuangan daerah adalah semua hak dan kewajiban daeah dalam rangka penyelenggaraan pemerintah daerah yang dapat dinilai dengan uang termasuk didalamnya segala bentuk kekayaan yang berhubungan dengan hak dan kewajiban daerah tersebut. Selanjutnya dalam Pasal 4 ayat (1) juga menjelaskan tentang Asas Umum Pengelolaan Keuangan Daerah yang menyatakan bahwa keuangan daerah dikelola secara tertib, taat pada peraturan perundang-undangan, efisien, ekonomis, transparan dan bertanggung jawab dengan memperhatikan asas keadilan, kepatutan dan manfaat untuk masyarakat.

Asas Umum tersebut lebih lanjut ditegaskan dalam Peraturan Menteri Dalam Negeri Nomor 13 Tahun 2006 tentang Pedoman Pengelolaan Keuangan Daerah yang menjelaskan bahwa: Efisien mencakup pencapaian keluaran maksimum dengan masukan tertentu atau menggunakan masukan terendah untuk mencapai keluaran tertentu, lalu transparan yaitu asas keterbukaan yang memungkinkan masyarakat mengetahui dan mendapatkan akses informasi seluas-luasnya tentang keuangan daerah. Sedangkan anggung jawab merupakan wujud kewajiban seseorang untuk mempertanggungjawabkan pengelolaan dan penguasaan 
sumber daya serta pelaksanaan kebijakan yang dipercayakan kepadanya dalam rangka pencapaian tujuan yang telah ditetapkan. Selanjutnya Asas Keadilan yang dimaksud adalah keseimbangan pembagian kewenangan dan pendanaan dan / atau keseimbangan pembagian hak dan kewajiban berdasarkan pertimbangan yang obyektif.

\section{Laporan Keuangan Daerah}

Laporan Keuangan Daerah dilaksanakan berdasarkan instruksi Peraturan Pemerintah Nomor 71 Tahun 2010 yang menguraikan bahwa laporan keuangan yang dikelola Pemerintah Daerah adalah laporan yang terbentuk mengenai keadaan keuangan dan transaksi-transaksi yang dilakukan oleh suatu pelaporan. Tujuan pelaporan keuangan pemerintah adalah menyajikan informasi yang berguna untuk pengambilan keputusan dan untuk menunjukkan akuntabilitas entitas pelaporan atas sumber daya yang dipercayakan kepadanya (Halim, 2014).

\section{Sistem Informasi Manajemen Daerah (SIMDA)}

Sistem Informasi Manajemen Daerah merupakan program aplikasi komputer yang terintegrasi sehingga diharapkan dapat membantu proses administrasi pemerintah daerah, yang terdiri dari 26 aplikasi terpisah. SIMDA disalurkan ke masing-masing SKPD dengan sistem yang terintegrasi, sehingga keluarannya dapat dimanfaatkan oleh pimpinan daerah untuk membantu proses pengambilan keputusan (Adriana, 2018).

BPKP (2008) dalam (Supriyanto, 2016) menyatakan bahwa ada empat indikator SIMDA, yaitu: 1) Akses: jaringan telekomunikasi, jaringan internet dan media komunikasi lainnya yang dapat digunakan oleh masyarakat untuk mengakses situs layanan publik; 2) Portal: layanan publik, situs web pemerintah di internet untuk penyedia layanan publik tertentu yang mengintegrasikan pemrosesan dan pengelolaan informasi dan dokumen elektronik di beberapa instansi terkait; 3) Organisasi pengelola dan pengolahan informasi pendukung organisasi yang mengelola, menyediakan dan mengolah informasi transaksi dan dokumen elektronik; dan 4) Infrastruktur dasar dan aplikasi seluruh infrastruktur, baik berupa 
perangkat keras maupun perangkat lunak yang dibutuhkan untuk mendukung pengelolaan, pemrosesan, transaksi, dan distribusi informasi.

\section{Tingkat Pemahaman Pengguna}

Pemahaman berasal dari kata mengerti yang artinya mengerti dengan benar, sedangkan pengertian adalah proses melakukan bagaimana memahami (Fajri \& Senja, 2008). Dalam hal ini terkait dengan pemahaman pengguna atau sumber daya manusia yang mengoperasikan SIMDA di masing-masing SKPD. Sumber Daya Manusia diharapkan memiliki kualitas untuk menghasilkan kinerja yang maksimal.

\section{Dukungan Manajemen Puncak}

Chen \& Paulraj (2004) mendefinisikan dukungan manajemen puncak sebagai komitmen terhadap waktu, biaya, dan sumber daya untuk mendukung pemasok sehingga kemitraan terjadi dalam jangka panjang dan perusahaan dapat mengambil proses yang stabil. Sedangkan menurut Hashmi (2004) pihak yang bertanggung jawab memberikan pedoman umum dalam kegiatan sistem informasi.

Indikator Dukungan Manajemen Puncak (top management support) menurut Chen \& Paulraj (2004) antara lain:

1) Decision Quality (Keputusan yang berkualitas). Keputusan yang berkualitas adalah inti dari perencanaan. Dalam hal ini kita melihat keputusan sebagai suatu cara bertindak paling efektif yang dipilih oleh manajer, penempatan untuk mencapai sasaran dan pemecahan masalah. Sehingga sesuai dengan keinginan dan harapan.

2) Decision Acceptance (Penerimaan Keputusan). Penerimaan keputusan adalah suatu reaksi terhadap beberapa solusi alternatif yang dilakukan secara sadar dengan cara menganalisa kemungkinan-kemungkinan dari alternatif tersebut bersama konsekuensinya. 
3) Satisfaction with the Decision Process (Kepuasan dengan proses Keputusan). Kepuasan dengan proses keputusan bahwa kepuasan sebagai respon emosional menunjukkan perasaan yang menyenangkan berkaitan dengan pandangan karyawan terhadap keputusan.

4) Development of Participant Skills (Membangun keahlian partisipan). Membangun keahlian partisipan adalah keterlibatan mental dan emosi serta fisik pegawai dalam memberikan respon terhadap kegiatan yang dilaksanakan dalam proses pengambilan keputusan serta mendukung pencapaian tujuan dan bertanggung jawab atas keterlibatannya.

\section{Kualitas Data}

Mosley (2008) menyebutkan kualitas data sebagai level data yang menyatakan data tersebut akurat, lengkap, update, konsisten sesuai dengan semua kebutuhan peraturan bisnis dan relevan. Data juga dapat didefinisikan sebagai kumpulan kejadian yang diangkat dari suatu kenyataan berupa angka-angka, huruf-huruf atau simbol-simbol khusus atau gabungan darinya (Jogiyanto, 2004). Proses produksi data harus berjalan dengan baik agar dapat mencapai hasil yang berkualitas (Lee \& Strong, 2003). Karena, data tidak dapat bercerita banyak sebelum data tersebut diolah lebih lanjut ke proses input dimana tahap ini merupakan proses memasukkan data kedalam komputer lewat alat input (input device).

\section{PENGEMBANGAN HIPOTESIS}

\section{Tingkat Pemahaman Pengguna terhadap Implementasi SIMDA}

Kesuksesan penggunaan software tergantung pada teknologi itu sendiri dan tingkat keahlian individu yang mengoperasikannya (Devi, 2013). Oleh karena itu, kegiatan pelatihan perlu dilakukan untuk membangun rasa percaya diri pengguna sehingga dapat mengantisipasi timbulnya kecemasan dan penolakan dari pengguna terhadap suatu sistem yang baru. Karena, ketidaktahuan atau kecemasan yang timbul dari pengguna terhadap 
sistem yang baru akan dapat menyebabkan kegagalan dalam menggunakan terknologi informasi. Pemahaman pengguna terkait teknologi informasi akan sangat menentukan keberhasilan suatu sistem informasi.

Peningkatan pemahaman pengguna pengguna sistem informasi tentunya akan mempengaruhi keberhasilan pemanfaatan teknologi informasi (Sunarti \& Nur, 1998). Hasil penelitian Hargo (2001) menyatakan bahwa tingkat pemahaman teknologi informasi memiliki dampak signifikan terhadap penerapan teknologi informasi. Devi (2013) juga menyatakan bahwa tingkat pemahaman pengguna mempengaruhi keberhasilan pelaksanaan sistem informasi akuntansi.

$\mathrm{H} 1$ : Tingkat pemahaman berpengaruh positif terhadap implementasi SIMDA

\section{Dukungan Manajemen Puncak terhadap Implementasi SIMDA}

Cooper (2006) menyatakan bahwa komitmen manajemen dipahami sebagai keterlibatan manajemen dalam mempertahankan perilaku untuk mencapai tujuan organisasi. Semakin meningkatkn komitmen manajemen terhadap perkembangan sistem akuntasi tentu saja akan memiliki dampak terhadapa kualitas implementasi sistem tersebut. Thong, CheeSIng, \& Raman (1996) menyatakan bahwa apabila tingkat dukungan dari manajemen puncak rendah, maka sangat kecil kemungkinan manajemen puncak untuk turut terlibat dalam pelaksanaan sistem informasi tersebut.

Penelitian ini menunjukkan bahwa untuk meningkatkan efektivitas sistem informasi yang ingin dicapai maka komitmen manajemen sangat diperlukan dengan cara menyediakan sumber daya yang dibutuhkan untuk pengembangan sistem informasi tersebut. Hasil penelitian Rahayu (2012) memberikan hasil bahwa adanya komitmen dari manajemen serta kualitas data memberikan pengaruh terhadap sistem informasi.

H2 : Dukungan manajemen puncak berpengaruh positif terhadap implementasi SIMDA

\section{Kualitas Data Input terhadap Implementasi SIMDA}


Kualitas data berhubungan dengan semua proses bagaimana cara menghasilkan data, yang dimulai dari mengumpulkan, menyimpan dan menggunakan data tersebut. Semuanya harus berjalan dengan baik agar data yang dihasilkan berkualitas. (Lee \& Strong, 2003) dalam Al-Hiyari, Ahmad, Al-ashhregy, Mat, \& Alekam (2013) menyatakan bahwa proses produksi data harus berjalan dengan baik agar dapat mencapai hasil yang berkualitas. Sejalan dengan hal ini, Rahayu (2012) menyatakan bahwa data yang berkualitas dapat mempengaruhi output dari sistem informasi, begitu pula dengan penelitian Xu (2003) menyatakan bahwa kualitas output sistem informasi sangat tergantung dari input data.

H3 : Kualitas data input berpengaruh positif terhadap implementasi SIMDA

\section{Tingkat Pemahaman Pengguna, Dukungan Manajemen Puncak dan Kualitas terhadap Implementasi SIMDA}

Grande, Estebanez, \& Colomina (2011) mendefinisikan SIA sebagai alat yang dirancang untuk membantu dalam pengelolaan dan pengendalian topik yang berkaitan dengan bidang keuangan, ekonomi dan korporasi. Sejalan dengan hal ini, Salehi, et al (2010) dalam penelitian memberikan hasil bahwa sistem informasi akuntansi dapat meningkatkan kinerja individu untuk menghasilkan laporan keuangan berkualitas.

Penelitian Xu (2003) menyatakan bahwa informasi yang tidak berkualitas dalam laporan keuangan dapat memberikan dampak yang buruk dalam pengambilan keputusan. Misalnya, kesalahan informasi peresediaan dapat menyebabkan pengambilan keputusan yang salah oleh manajer. Informasi yang berkualitas dalam laporan keuangan harus mengandung empat atribut ini: akurasi, ketepatan waktu, kelengkapan dan konsistensi. Sejalan dengan itu, Mc. Leod \& Schell (2007) menyatakan kualitas informasi diukur dengan empat dimensi, yaitu relevansi, akurasi, ketepatan waktu dan kelengkapan.

H4 : Tingkat Pemahaman Pengguna, Dukungan Manajemen Puncak dan Kualitas Data Secara Simultan berpengaruh positif terhadap Implementasi Sistem Informasi Manajemen Daerah 


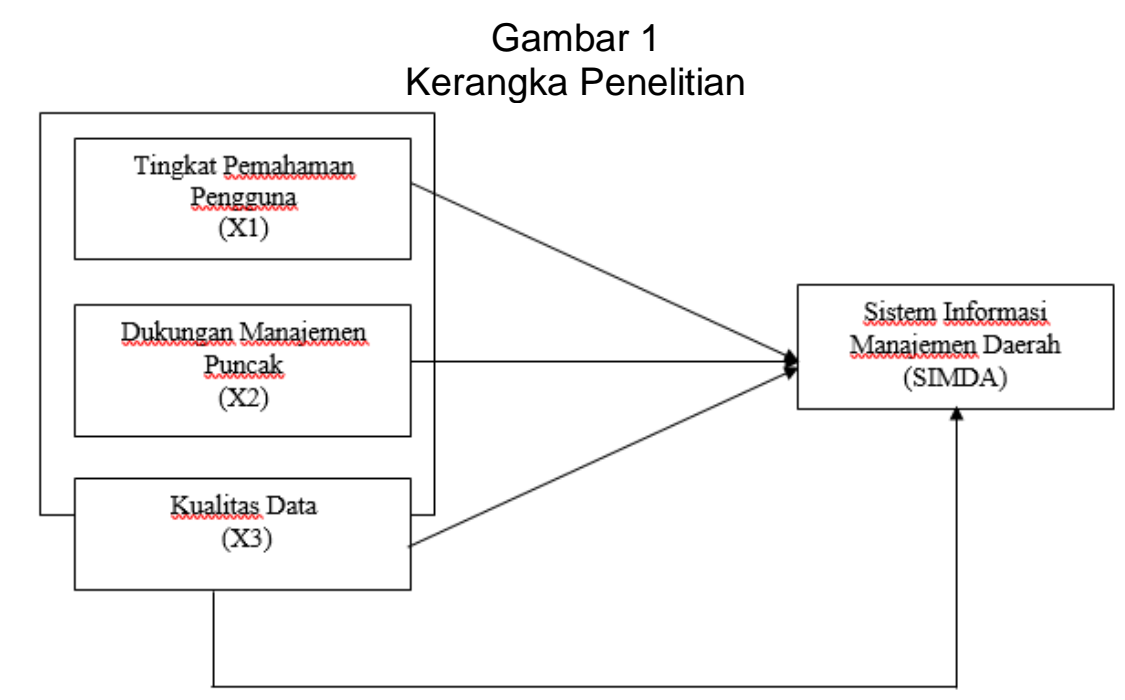

\section{METODE PENELITIAN}

Penelitian ini merupakan penelitian eksplanatory karena berupaya untuk menjelaskan implementasi system informasi manajemen daerah di Kabupaten Sarmi. Pendekatan yang digunakan dalam penelitian adalah pendekatan kuantitatif, dengan model penelitian survey dimana menggunakan instrument kuisioner untuk mendapatkan data opini responden kemudian dilakukan pengujian hipotesis (Jogiyanto, 2008).

Penelitian dilakukan pada Organisasi Perangkat Daerah Kabupaten Sarmi. Teknik pengambilan sampel menggunakan purposive sampling, dengan kriteria: 1) pegawai negeri sipil pada Organisasi Perangkat Daerah Kabupaten Sarmi yang berkedudukan sebagai bendahara dan kepala Sub Bagian Keuangan/Kepala Sub Bagian Akuntanis; dan 2) pegawai yang telah bekerja minimal 2 tahun pada OPD tersebut. Adapun total sampel dalam penelitian ini sebanyak 71 responden dari 57 Organisasi Perangkat Daerah (Badan/Dinas/Biro, Inspektorat dan Kantor).

Adapun defisini operasional dan pengukuran dari setiap variabel antara lain:

1. Pemahaman Pengguna (X1)

Pengguna atau sering juga disebut dengan user yang dimaksud disini adalah sumberdaya manusia (SDM) yang mengoperasikan aplikasi SIMDA pada setiap SKPD. SDM atau sumber daya manusia mengandung dua definisi; 1) pekerjaan bisnis atau layanan yang dapat diberikan dalam proses produksi. Dalam hal lain, SDM 
mencerminkan kualitas usaha yang diberikan oleh seseorang dalam waktu tertentu untuk menghasilkan barang dan jasa; dan 2) sumber daya manusia yang bersangkutan yang dapat bekerja untuk menyediakan jasa atau usaha kerja. Penelitian ini menggunakan 8 item pernyataan yang diukur dengan skala likert 1-5.

2. Dukungan Manajemen Puncek (X2)

Chen \& Paulraj (2004) mendefinisikan dukungan manajemen puncak sebagai berikut: komitmen terhadap waktu, biaya, dan sumber daya untuk mendukung pemasok sehingga kemitraan terjadi dalam jangka panjang dan perusahaan juga dapat menjalankan proses yang stabil. Salah satu hal yang penting untuk manajemen puncak dalam menjalankan bisnis adalah untuk dapat selalu mengembangkan dan menciptakan nilai bagi perusahaan untuk meningkatkan kinerja organisasi. Penelitian ini menggunakan 8 item pernyataan yang diukur dengan skala likert 1-5.

3. Kualitas Data (X3)

Sebuah kumpulan peristiwa yang diangkat dari suatu fakta, data dapat berupa angka, huruf atau simbol khusus, atau kombinasinya (Jogiyanto, 2004). Data tidak dapat memberi tahu banyak sebelum data diproses lebih lanjut ke proses input dimana tahap ini adalah proses memasukkan data ke dalam komputer melalui perangkat input. Dalam kajian ini, pengukuran variabel merujuk kepada penelitian yang dilakukan oleh (Alfian, 2014).Penelitian ini menggunakan 7 item pernyataan yang diukur dengan skala likert 1-

5.

4. Sistem Informasi Manajemen Daerah $(\mathrm{Y})$

Kerangka kerja arsitektural SIMDA terdiri dari empat lapis struktur (BPKP, 2008), antara lain: 1) akses, jaringan telekomunikasi, Jaringan internet, dan media komunikasi lainnya yang dapat digunakan oleh masyarakat untuk mengakses situs pelayanan publik; 2) portal, Layanan publik, situs web pemerintah di internet untuk penyedia layanan publik tertentu yang mengintegrasikan pengolahan dan pengelolaan informasi dan dokumen elektronik di sejumlah instansi terkait; 3. pengolahan informasi dan organisasi 
manajemen mendukung organisasi yang mengelola, menyediakan dan memproses informasi transaksi dan dokumen elektronik; dan 4. infrastruktur dan aplikasi dasar dari semua infrastruktur, baik dalam bentuk perangkat keras dan perangkat lunak, diperlukan untuk mendukung manajemen, pengolahan, transaksi, dan distribusi informasi. Penelitian ini menggunakan 8 item pernyataan yang diukur dengan skala likert 1-5.

Menurut (Hartono, 2005))analisis regresi berganda digunakan oleh peneliti bila peneliti bermaksud meramalkan bagaimana keadaan (naik turunnya) variabel dependen, bila dua atau lebih variabel independen sebagai factor predictor dimanipulasi (dinaik turunkan nilainya). Motode ini digunakan untuk mengetahui variabel yang dominan memberi sumbangan terhadap variabel terikat untuk mengetahui pengaruh antara dua variabel atau lebih, yaitu variabel bebas dan variabel terikat. Adapun rumusnya adalah sebagai berikut:

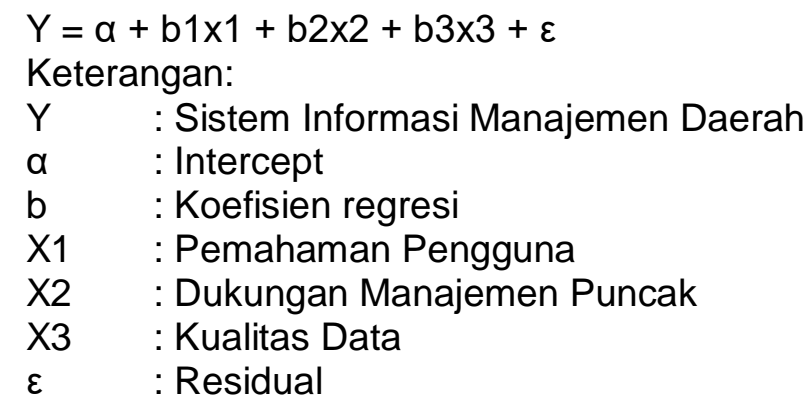

\section{HASIL DAN PEMBAHASAN}

Jumlah kuisioner yang disebarkan sebanyak 114, dari jumlah tersebut sebanyak 29 kuisioner (25\%) yang tidak kembali, 14 kuisioner (12\%) yang rusak/tidak dapat diolah dan yang dapat diolah sebanyak 71 kuisioner (63\%). Karakteristik responden berdasarkan jabatan strukturalnya terdiri dari 13 orang (18\%) Kabid/Kabag Keuangan, 11 orang (15\%) Sekretaris, 47 orang (66\%) Bendahara, dengan rata-rata lama bekerja 6 sampai dengan 10 tahun.

\section{Distribusi Frekuensi Jawaban Responden Tentang Pemahaman Pengguna}

Berikut ini adalah deskripsi jawaban responden mengenai variabel pemahaman pengguna: 
Tabel 1

Distribusi Frekuensi Jawaban Responden Tentang Pemahaman Pengguna

\begin{tabular}{|c|c|c|c|c|c|c|c|c|c|c|c|c|c|}
\hline \multirow{3}{*}{ Item } & \multicolumn{12}{|c|}{ Frekuensi Jawaban } & \multirow{3}{*}{$\begin{array}{c}\begin{array}{c}\text { Rata- } \\
\text { rata }\end{array} \\
\%\end{array}$} \\
\hline & \multicolumn{2}{|c|}{5} & \multicolumn{2}{|c|}{4} & \multicolumn{2}{|c|}{3} & \multicolumn{2}{|c|}{2} & \multicolumn{2}{|c|}{1} & \multicolumn{2}{|c|}{ Total } & \\
\hline & $\mathrm{F}$ & $\%$ & $\mathrm{~F}$ & $\%$ & $F$ & $\%$ & $F$ & $\%$ & $F$ & $\%$ & $F$ & $\%$ & \\
\hline$X_{1.1}$ & 29 & $41 \%$ & 40 & $56 \%$ & 2 & $3 \%$ & 0 & $0 \%$ & 0 & $0 \%$ & 71 & $100 \%$ & 4.38 \\
\hline$\overline{X_{1.2}}$ & 27 & $38 \%$ & 38 & $54 \%$ & 4 & $6 \%$ & 2 & $2 \%$ & 0 & $0 \%$ & 71 & $100 \%$ & 4.27 \\
\hline$\overline{X_{1.3}}$ & 32 & $45 \%$ & 35 & $49 \%$ & 3 & $4 \%$ & 1 & $2 \%$ & 0 & $0 \%$ & 71 & $100 \%$ & 4.38 \\
\hline$X_{1.4}$ & 29 & $41 \%$ & 40 & $56 \%$ & 2 & $3 \%$ & 0 & $0 \%$ & 0 & $0 \%$ & 71 & $100 \%$ & 4.38 \\
\hline$\overline{X_{1.5}}$ & 27 & $38 \%$ & 38 & $54 \%$ & 4 & $6 \%$ & 2 & $2 \%$ & 0 & $0 \%$ & 71 & $100 \%$ & 4.27 \\
\hline$X_{1.6}$ & 32 & $45 \%$ & 35 & $49 \%$ & 3 & $4 \%$ & 1 & $2 \%$ & 0 & $0 \%$ & 71 & $100 \%$ & 4.38 \\
\hline$X_{1.7}$ & 22 & $31 \%$ & 42 & $59 \%$ & 7 & $10 \%$ & 0 & 0 & 0 & 0 & 71 & $100 \%$ & 4.21 \\
\hline $\mathrm{X}_{1.8}$ & 24 & $34 \%$ & 39 & $55 \%$ & 8 & $11 \%$ & 0 & 0 & 0 & 0 & 71 & $100 \%$ & 4.23 \\
\hline & & & & ta T & & ma & & gun & & & & & 4.31 \\
\hline
\end{tabular}

Hasil analisis pada tabel 1 terkait jawaban responden tentang variabel pemahaman pengguna yang diukur dengan 8 item pernyataan memberikan nilai rata-rata $4,31 \%$. Hasil ini menunjukkan bahwa variabel ini mampu dijelaskan dengan baik oleh pernyataan-pernyataan di atas. Pernyataan yang relative lebih baik dalam menjelaskan variabel ini adalah pernyataan $\mathrm{X} 1.1 ; \mathrm{X} 1.3 ; \mathrm{X} 1.4$ dan $\mathrm{X} 1.6$ yang berisi pernyataan terkait kemudahan penggunaan aplikasi Sistem Informasi Manajemen Daerah.

\section{Distribusi Frekuensi Jawaban Responden Tentang Dukungan Manajemen Puncak}

Berikut ini adalah deskripsi jawaban responden mengenai variabel dukungan manajemen puncak:

Tabel 2

Distribusi Frekuensi Jawaban Responden Tentang Dukungan Manajemen Puncak

\begin{tabular}{|c|c|c|c|c|c|c|c|c|c|c|c|c|c|}
\hline \multirow{3}{*}{ Item } & \multicolumn{12}{|c|}{ Frekuensi Jawaban } & \multirow{3}{*}{$\begin{array}{c}\begin{array}{c}\text { Rata- } \\
\text { rata }\end{array} \\
\%\end{array}$} \\
\hline & \multicolumn{2}{|c|}{5} & \multicolumn{2}{|c|}{4} & \multicolumn{2}{|c|}{3} & \multicolumn{2}{|c|}{2} & \multicolumn{2}{|c|}{1} & \multicolumn{2}{|c|}{ Total } & \\
\hline & $\mathbf{F}$ & $\%$ & $\mathbf{F}$ & $\%$ & $\mathbf{F}$ & $\%$ & $\mathbf{F}$ & $\%$ & $\mathbf{F}$ & $\%$ & $\mathbf{F}$ & $\%$ & \\
\hline $\mathrm{X}_{2.1}$ & 29 & $41 \%$ & 40 & $56 \%$ & 2 & $3 \%$ & 0 & $0 \%$ & 0 & $0 \%$ & 71 & $100 \%$ & 4.38 \\
\hline $\mathrm{X}_{2.2}$ & 27 & $38 \%$ & 35 & $49 \%$ & 8 & $11 \%$ & 1 & $2 \%$ & 0 & $0 \%$ & 71 & $100 \%$ & 4.24 \\
\hline$X_{2.3}$ & 24 & $34 \%$ & 41 & $58 \%$ & 5 & $7 \%$ & 1 & $2 \%$ & 0 & $0 \%$ & 71 & $100 \%$ & 4.24 \\
\hline $\mathrm{X}_{2.4}$ & 27 & $38 \%$ & 38 & $54 \%$ & 6 & $8 \%$ & 0 & $0 \%$ & 0 & $0 \%$ & 71 & $100 \%$ & 4.3 \\
\hline $\mathrm{X}_{2.5}$ & 32 & $45 \%$ & 35 & $49 \%$ & 4 & $6 \%$ & 0 & $0 \%$ & 0 & $0 \%$ & 71 & $100 \%$ & 4.39 \\
\hline $\mathrm{X}_{2.6}$ & 22 & $31 \%$ & 42 & $59 \%$ & 7 & $10 \%$ & 0 & $0 \%$ & 0 & $0 \%$ & 71 & $100 \%$ & 4.21 \\
\hline $\mathrm{X}_{2.7}$ & 24 & $34 \%$ & 39 & $55 \%$ & 8 & $11 \%$ & 0 & $0 \%$ & 0 & $0 \%$ & 71 & $100 \%$ & 4.23 \\
\hline \multicolumn{13}{|c|}{ Rata-rata Dukungan Manajemen Puncak } & 4.28 \\
\hline
\end{tabular}


Hasil analisis pada tabel 2 terkait jawaban responden tentang variabel dukungan manajemen puncak yang diukur dengan 7 item pernyataan memberikan nilai rata-rata 4,28 \%. Hasil ini menunjukkan bahwa variabel ini mampu dijelaskan dengan baik oleh pernyataan-pernyataan di atas. Pernyataan yang relative lebih baik dalam menjelaskan variabel ini adalah pernyataan $\mathrm{X}_{2.5}$ yang berisi pernyataan terkait terkait harapan yang tinggi dari manajemen puncak terhadap penggunaan SIMDA.

\section{Distribusi Frekuensi Jawaban Responden Tentang Kualitas Data}

Berikut ini adalah deskripsi jawaban responden mengenai variabel kualitas data:

Tabel 3

Distribusi Frekuensi Jawaban Responden Tentang Kualitas Data

\begin{tabular}{|c|c|c|c|c|c|c|c|c|c|c|c|c|c|}
\hline \multirow{3}{*}{ Item } & \multicolumn{12}{|c|}{ Frekuensi Jawaban } & \multirow{3}{*}{$\begin{array}{c}\text { Rata- } \\
\text { rata }\end{array}$} \\
\hline & \multicolumn{2}{|c|}{5} & \multicolumn{2}{|c|}{4} & \multicolumn{2}{|c|}{3} & \multicolumn{2}{|c|}{2} & \multicolumn{2}{|c|}{1} & \multicolumn{2}{|c|}{ Total } & \\
\hline & $\mathbf{F}$ & $\%$ & $\mathbf{F}$ & $\%$ & $\mathbf{F}$ & $\%$ & $\mathbf{F}$ & $\%$ & $\mathbf{F}$ & $\%$ & $\mathbf{F}$ & $\%$ & \\
\hline$X_{3.1}$ & 22 & $31 \%$ & 38 & $54 \%$ & 2 & $3 \%$ & 9 & $13 \%$ & 0 & $0 \%$ & 71 & $100 \%$ & 3.77 \\
\hline$X_{3.2}$ & 24 & $34 \%$ & 32 & $45 \%$ & 11 & $15 \%$ & 4 & $6 \%$ & 0 & $0 \%$ & 71 & $100 \%$ & 4.07 \\
\hline$X_{3.3}$ & 26 & $37 \%$ & 32 & $45 \%$ & 4 & $6 \%$ & 9 & $13 \%$ & 0 & $0 \%$ & 71 & $100 \%$ & 4.06 \\
\hline$X_{3.4}$ & 20 & $28 \%$ & 36 & $51 \%$ & 12 & $17 \%$ & 3 & $4 \%$ & 0 & $0 \%$ & 71 & $100 \%$ & 4.03 \\
\hline$X_{3.5}$ & 21 & $30 \%$ & 38 & $54 \%$ & 4 & $6 \%$ & 8 & $11 \%$ & 0 & $0 \%$ & 71 & $100 \%$ & 4.01 \\
\hline$X_{3.6}$ & 27 & $38 \%$ & 31 & $44 \%$ & 4 & $6 \%$ & 9 & $13 \%$ & 0 & $0 \%$ & 71 & $100 \%$ & 4.07 \\
\hline$X_{3.7}$ & 23 & $32 \%$ & 31 & $44 \%$ & 8 & $11 \%$ & 8 & $11 \%$ & 1 & $1 \%$ & 71 & $100 \%$ & 3.93 \\
\hline$X_{3.8}$ & 22 & $31 \%$ & 31 & $44 \%$ & 12 & $17 \%$ & 3 & $4 \%$ & 3 & $4 \%$ & 71 & $100 \%$ & 3.89 \\
\hline \multicolumn{13}{|c|}{ Rata-rata Kualitas Data } & 3.98 \\
\hline
\end{tabular}

Hasil analisis pada tabel 3 terkait jawaban responden tentang variabel kualitas data yang diukur dengan 8 item pernyataan memberikan nilai rata-rata $3,98 \%$. Hasil ini menunjukkan bahwa variabel ini mampu dijelaskan dengan baik oleh pernyataan-pernyataan di atas. Pernyataan yang relative lebih baik dalam menjelaskan variabel ini adalah pernyataan $X_{3.2}$ dan $X_{3.6}$ yang berisi pernyataan terkait terkait adanya penyampaian informasi mengenai ketidakberhasilan pencapaian OPD dalam laporan keuangannya dan tampilan data yang mudah dipahami.

Distribusi Frekuensi Jawaban Responden Tentang Sistem Informasi Manajemen Daerah (SIMDA) 
Berikut ini adalah deskripsi jawaban responden mengenai variabel system informasi manajemen daerah:

Tabel 4

Distribusi Frekuensi Jawaban Responden Tentang Sistem Informasi Manajemen Daerah

\begin{tabular}{|c|c|c|c|c|c|c|c|c|c|c|c|c|c|}
\hline \multirow{3}{*}{ Item } & \multicolumn{12}{|c|}{ Frekuensi Jawaban } & \multirow{3}{*}{$\begin{array}{c}\begin{array}{r}\text { Rata- } \\
\text { rata }\end{array} \\
\%\end{array}$} \\
\hline & \multicolumn{2}{|c|}{5} & \multicolumn{2}{|c|}{4} & \multicolumn{2}{|c|}{3} & \multicolumn{2}{|c|}{2} & \multicolumn{2}{|c|}{1} & \multicolumn{2}{|c|}{ Total } & \\
\hline & $\mathbf{F}$ & $\%$ & $\mathbf{F}$ & $\%$ & $\mathbf{F}$ & $\%$ & $\mathbf{F}$ & $\%$ & $\mathbf{F}$ & $\%$ & $\mathbf{F}$ & $\%$ & \\
\hline $\mathrm{Y}_{1.1}$ & 22 & $31 \%$ & 40 & $56 \%$ & 9 & $13 \%$ & 0 & $0 \%$ & 0 & $0 \%$ & 71 & $100 \%$ & 4.18 \\
\hline $\mathrm{Y}_{1.2}$ & 27 & $38 \%$ & 38 & $54 \%$ & 4 & $6 \%$ & 2 & $3 \%$ & 0 & $0 \%$ & 71 & $100 \%$ & 4.27 \\
\hline $\mathrm{Y}_{1.3}$ & 25 & $35 \%$ & 35 & $49 \%$ & 10 & $13 \%$ & 1 & $2 \%$ & 0 & $0 \%$ & 71 & $100 \%$ & 4.18 \\
\hline $\mathrm{Y}_{1.4}$ & 23 & $32 \%$ & 40 & $56 \%$ & 8 & $11 \%$ & 0 & $0 \%$ & 0 & $0 \%$ & 71 & $100 \%$ & 4.21 \\
\hline $\mathrm{Y}_{1.5}$ & 27 & $38 \%$ & 38 & $54 \%$ & 4 & $6 \%$ & 2 & $3 \%$ & 0 & $0 \%$ & 71 & $100 \%$ & 4.27 \\
\hline$Y_{1.6}$ & 30 & $42 \%$ & 31 & $44 \%$ & 8 & $11 \%$ & 2 & $3 \%$ & 0 & $0 \%$ & 71 & $100 \%$ & 4.25 \\
\hline$Y_{1.7}$ & 22 & $31 \%$ & 31 & $44 \%$ & 12 & $17 \%$ & 3 & $4 \%$ & 3 & $4 \%$ & 71 & $100 \%$ & 3.89 \\
\hline$Y_{1.8}$ & 24 & $34 \%$ & 35 & $49 \%$ & 8 & $11 \%$ & 4 & $6 \%$ & 0 & 0 & 71 & $100 \%$ & 4.11 \\
\hline \multicolumn{13}{|c|}{ Rata-rata Sistem Informasi Manajemen Daerah (SIMDA) } & 4.17 \\
\hline
\end{tabular}

Hasil analisis pada tabel 4 terkait jawaban responden tentang variabel kualitas data yang diukur dengan 8 item pernyataan memberikan nilai rata-rata $4,17 \%$. Hasil ini menunjukkan bahwa variabel ini mampu dijelaskan dengan baik oleh pernyataan-pernyataan di atas. Pernyataan yang relative lebih baik dalam menjelaskan variabel ini adalah pernyataan $\mathrm{Y}_{1.2}$ dan $\mathrm{Y}_{1.5}$ yang berisi pernyataan terkait penggunaan SIMDA dalam prosedur akuntansi.

\section{Uji Validitas dan Reliabilitas}

Pengujian validitas menggunakan perbandingan antara indeks korelasi Product Moment Person dengan signifikansi 5\%, yang mana bila signifikansi lebih kecil dari 0,05 maka instrument dinyatakan valid. Dalam penelitian ini peroleh hasil bahwa semua intrument yang diukur dinyatakan valid karena tingkat probabilitasnya atau signifikansi lebih kecil dari 0,05 atau 5\%. Kemudian nilai reliabilitasnya dilihat dari nilai Cronbach's Alpha dengan nilai > 0,6. Bila nilai Cronbach's Alpha > 0,6 maka variabel dinyatakan valid (Arikunto, 2011). Semua variabel dalam penelitian ini dinyatakan reliabel karena memiliki nilai Cronbach's Alpha $>0,6$. 


\section{Analisis Regresi Berganda}

Berikut ini adalah hasil pengujian dengan menggunakan analisis regresi berganda dengan bantuan software SPSS (Statistical Package fo Social Science), dengan hasil seperti di bawah ini: 
Tabel 5

Hasil Analisis Regresi

\begin{tabular}{|l|l|l|l|l|}
\hline \multicolumn{1}{|c|}{ Variabel } & $\begin{array}{l}\text { Standarized } \\
\text { Coefficients }\end{array}$ & $\begin{array}{c}\text { t } \\
\text { Hitung }\end{array}$ & Sig & \multicolumn{1}{c|}{ Ket } \\
\hline Constant & $-1,139$ & & & \\
\hline Tingkat Pemahaman Pengguna & 0,549 & 5,169 & 0,000 & Bepengaruh \\
\hline Dukungan Manajemen Puncak & 0,489 & 3,527 & 0,001 & Berpengaruh \\
\hline Kualitas Data & 0,246 & 1,977 & 0,052 & Tidak Berpengaruh \\
\hline R Square & 0,714 & & \\
\hline Adjusted R Square & 0,701 & & \\
\hline Tabel & 1,670 & & \\
\hline F Tabel & 3,130 &
\end{tabular}

\section{Pengujian Hipotesis dan Pembahasan}

Pengujian hipotesis dalam penelitian ini dilakukan dengan asumsi bahwa: $\mathrm{H}_{\mathrm{a}}$ diterima jika $t_{\text {hitung }}>t_{\text {tabel }}$ dengan kata lain ada pengaruh variabel independen terhadap system informasi manajemen daerah, sedangkan $\mathrm{H}_{0}$ diterima jika $t_{\text {hitung }}<\mathrm{t}_{\text {tabel }}$ dengan kata lain variabel independen tidak mempengaruhi system informasi manajemen daerah.

\section{Hipotesis Pertama: Tingkat Pemahaman Pengguna dan Sistem Informasi Manajemen}

\section{Daerah}

Berdasarkan analisis regresi diperoleh hasil bahwa variabel tingkat pemahaman pengguna berpengaruh signifikan terhadap system informasi manajemen daerah. Hal ini ditunjukkan dengan nilai $t_{\text {hitung }}=5,169>t_{\text {tabel }}=1,670$ dengan nilai koefisien regresi sebesar 0,000. Sehingga dapat disimpulkan bahwa hipotesis pertama diterima.

Hal ini berarti bahwa hubungan tingkat pemahaman pengguna (SDM) searah dengan implementasi Sistem Informasi Manajemen Daerah (SIMDA). Hasil penelitian ini sesuai dengan penelitian yang di lakukan oleh Alfian (2014) yang meneliti tentang analisis faktor-faktor yang mendukung implementasi Sistem Informasi Manajemen Daerah (SIMDA) dan pengaruhnya terhadap laporan keuangan. Hasil penelitian menunjukan bahwa tingkat pemahaman pengguna berpengaruh signifikan positif terhadap implementasi Sistem Informasi Manajemen Daerah (SIMDA). Begitu juga dengan Penelitian yang dilakukan 
Diwasya, (2016); Kamal \& Noermansyah (2010) dimana tingkat pemahaman pengguna juga mempunyai pengaruh terhadap implementasi Sistem Informasi Manajemen Daerah (SIMDA).

Dari penelitian ini dapat disimpulkan bahwa semakin tinggi tingkat pemahaman penggunaan akan semakin mempengaruhi implementasi Sistem Informasi Manajemen Daerah (SIMDA). Sama halnya dengan kualitas sumber daya manusia dapat mempengaruhi implementasi Sistem Informasi Manajemen Daerah (SIMDA). Tingkat pemahaman pengguna harus diperhatikan dengan baik agar terlaksananya implemntasi Sistem Informasi Manajemen Daerah (SIMDA) sesuai dengan perencanaan pemerintah daerah. Semakin tinggi tingkat pemahaman pengguna maka dapat membantu meningkatkan implementasi Sistem Informasi Manajemen Daerah (SIMDA) di pemerintah daerah. Logikanya dengan adanya pemahaman pengguna memperluas pengetahuan tentang implementasi Sistem Informasi Manajemen Daerah (SIMDA). Dalam pengimplementasian SIMDA pemerintah harus menyelenggarakan pelatihan untuk meminimalisir penolakan terhadap aplikasi Sistem Informasi Manajemen Daerah (SIMDA).

Hal lain yang harus menjadi perhatian adalah kesiapan dan kemauan untuk menerima dan melaksanakan perubahan. Untuk dapat menentukan keberhasilan suatu sistem informasi, dibutuhkan pemahaman oleh pengguna sistem tersebut (Alfian, 2014). Di era yang moderen ini setiap pegawai pada SKPD harus memiliki ketanggapan yang cepat, karena hal ini akan berpengaruh juga terhadap jalannya SKPD. Dengan adanya perubahan inilah yang dapat melaksanakan implementasi Sistem Informasi Manajemen Daerah (SIMDA) lebih baik lagi.

Hipotesis Kedua: Dukungan Manajemen Puncak dan Sistem Informasi Manajemen Daerah

Berdasarkan analisis regresi diperoleh hasil bahwa variabel dukungan manajemen puncak berpengaruh signifikan terhadap system informasi manajemen daerah. Hal ini ditunjukkan dengan nilai $t_{\text {hitung }}=3,527>t_{\text {tabel }}=1,670$ dengan nilai koefisien regresi sebesar 0,000. Sehingga dapat disimpulkan bahwa hipotesis kedua diterima. 
Faktor penting dalam menentukan keberhasilan semua kegiatan yang berhubungan dengan sistem informasi adalah dukungan yang diberikan oleh manajemen puncak. Artinya bahwa semakin baik dukungan manajemen puncak yang diberikan pada suatu SKPD, maka semakin baik jalannya implementasi SIMDA. Jika dikaitkan denga karekteristik responden dan obje penelitian maka dapat dilihat bahwa manajemen puncak yaitu para kepala bidang yang telah cukup pengalaman dalam memberikan pengarahan bagi pengguna Sistem Informasi Manjemen Daerah sehingga para staf keuangan selaku pengguna system dapat mengartikan secara jelas maksud-maksud ataupun penjelasan pihak manajemen puncak dalam pengaplikasian Sistem Informasi Manajemen Daerah.

Hasil penelitian ini sejalan dengan penelitian yang dilakukan oleh Setiawati (2015), yang meneliti tentang analisis faktor pendukung implementasi SIMDA dan kualitas laporan keuangan di Labuhan Batu. Hasil penelitiannya menunjukan dukungan manajemen puncak berpengaruh signifikan positif terhadap implementasi SIMDA. Agar program yang digunakan atau yang akan digunakan berhasil, dibutuhkan dukungan pimpinan atau atasan. Keterlibatan mental dan emosi serta fisik dari pimpinan dalam memberikan respon terhadap program atau kegiatan yang dilaksanakan adalah cara yang paling efektif untuk mencapai kesuksesan program tersebut.

\section{Hipotesis Ketiga: Kualitas Data dan Sistem Informasi Manajemen Daerah}

Berdasarkan analisis regresi diperoleh hasil bahwa variabel kualitas data berpengaruh signifikan terhadap system informasi manajemen daerah. Hal ini ditunjukkan dengan nilai $t_{\text {hitung }}=1,977>t_{\text {tabel }}=1,670$ dengan nilai koefisien regresi sebesar 0,000 . Sehingga dapat disimpulkan bahwa hipotesis ketiga diterima.

Hal tersebut berkaitan dengan teori model penerimaan teknologi (TAM) lebih sederhana dan sebagai model yang memiliki landasan teori cukup kuat untuk digunakan serta model TAM ini terkait dengan sikap interest dan relevansinya terhadap interaksi personal. Hasil penelitian ini sesuai dengan penelitian yang di lakukan oleh Diwasya (2016) yang meneliti tentang analisis faktor pendukung implementasi SIMDA dan pengaruhnya 
terhadap kualitas laporan keuangan di pemerintah daerah Kab. Labuhan Batu dimana kualitas data juga berpengaruh terhadap Implementasi SIMDA.

Jika dilihat dari tabel distribusi frekuensi nilai rata-rata kualitas data di kategorikan baik dengan nilai 3,98. Ketersedian data yang di imput harus tetap ada, karena ketersediaan data tersebut akan mempengaruhi kualitas data yang diproses. Jika data yang akan di imput tersebut tidak tersedia maka akan mempengaruhi proses kerja pegawai OPD. Oleh karena itu ketersediaan data sangat dibutuhkan agar tidak menggangu proses kerja pegawai OPD.

Hipotesis Keempat: Tingkat Pemahaman Pengguna, Dukungan Manajemen Puncak, Kualitas Data dan Sistem Informasi Manajemen Daerah

Berdasarkan analisis regresi diperoleh hasil bahwa variabel tingkat pemahaman pengguna, dukungan manajemen puncak dan kualitas data secara simultasn berpengaruh signifikan terhadap system informasi manajemen daerah. Hal ini ditunjukkan dengan nilai $t_{\text {hitung }}=55,750>t_{\text {tabel }}=3,130$ dengan nilai koefisien regresi sebesar 0,000 . Sehingga dapat disimpulkan bahwa hipotesis keempat diterima.

Penelitian ini sejalan dengan Arba'in (2018) menyatakan Pemahaman Pengguna (X1), Dukungan Manajemen Puncak (X2) dan Kualitas Data (X3) secara bersama-sama (simultan) berpengaruh positif dan signifikan terhadap Implementasi Sistem Informasi Manajemen Daerah (SIMDA) Pemerintah Kabupaten Sarmi (Y).

Hal ini terkait dengan karakteristik responden penelitian yang dianggap telah mampu mengikuti perkembangan arus teknologi informasi di era modern ini. Tingkat pendidikan dan pemahaman para pengguna system yang sangat baik inilah yang mengakibatkan adanya pengaruh positif setiap variable dependen terhadap Implementasi Sistem Informasi Manajemen Daerah (SIMDA) Pemerintah Kabupaten Sarmi (Y). 


\section{KESIMPULAN}

Dari penelitian ini dapat ditarik kesimpulan bahwa variabel tingkat pemahaman pengguna, dukungan manajemen puncak dan kualitas data berpengaruh signifikan baik secara parsial maupun simultan terhadap implementasi system informasi manajemen daerah (SIMDA) di Kabupaten Sarmi.

Penelitian ini memberikan saran kepada peneliti lain untuk menambah variabel lain untuk penelitian serupa, misalnya faktor demografi, faktor lingkungan dan budaya organisasi. Diharapkan juga pengukuran variabel tidak dilakukan sebatas pada persepsi responden saja, tetapi dapat pula dilakukan melalui wawancara. Kehadiran peneliti pada saat responden melakukan pengisian kuisioner sebaiknya juga dilakukan, hal ini untuk menghindari respon bias sehingga responden dapat menanyakan secara langsung mengenai pertanyaan yang kurang dipahami.

\section{DAFTAR PUSTAKA}

Adriana, F. S. (2018). Peranan Sistem Informasi Manajemen Daerah (SIMDA) Terhadap Efektivitas Kerja Di Bagian Otonomi Daerah Sekretariat Kabupaten Kutai Timur. Administrasi Publik, 1(2), 121-125.

Al-Hiyari, Ahmad, Al-ashhregy, M. H. H., Mat, N. K. N., \& Alekam, J. M. (2013). Factors that Affect Accounting Information System Implementation and Accounting Information Quality: A Survey in University Utara Malaysia. American Journal of Economics 2013, 3(1), 27-31.

Alfian, M. (2014). Analisis Faktor Pendukung Implemetasi SIMDA dan Pengaruhnya Terhadap Kualitas Laporan Keuangan Pada SKPD (Penelitian pada SKPD di Lingkungan Pemerintah Daerah Kabupaten Kulon Progo). 3rd Economics \& Business Research Festival 2014.

Arba'in, F. D. (2018). Pengaruh Tingkat Pemahaman Pengguna, Dukungan Manajemen Puncak dan Kualitas Data terhadap Implementasi SIMDA (Studi Empiris pada SKPD Pemerintahan Kota Pariaman). Jurnal Akuntansi, 6(1).

BPKP. (2020). Daputi Was. Bidang Penyelenggaraan Keuangan Daerah.

Chen, I. J., \& Paulraj, A. (2004). Towards a Theory of Supply Chain Management: The Constructs and Measurements. Journal of Operations Management, 22(2), 119-150.

Cooper, D. (2006). The Impact of Management's Commitment on Employee Behavior: A Field Study. American Society of Safely Engineers.

Davis, F. . (1986). A Technology acceptance model for empirically testing new-end user information systems: Theory and Result. Sloan: Sloan School of Management, Massachusetss Institur of Technology (MIT).

Devi, V. F. (2013). Pengaruh Implementasi Sistem Informasi Akuntansi Terhadap Kinerja Organisasi Pemerintah Daerah (Penelitian pada SKPD di Lingkungan Pemerintah 
Daerah Kabupaten Kulon Progo). Universitas Muhammadiyah Yogyakarta.

Dewi, A. K., \& Senggarang, J. P. (2014). Pengaruh Kualitas Sistem Informasi Aplikasi SIMDA

(Sistem Informasi Manajemen Keuangan Daerah) Terhadap Kepuasan Pengguna Akhir

Studi Kasus pada Pemerintahan Provinsi Kepulauan Riau. Retrieved from jurnal.umrah.ac.id

Diwasya, I. R. (2016). Analisis Faktor-Faktor yang Mempengaruhi Implementasi SIMDA dan Pengaruhnya Terhadap Kualitas Laporan Keuangan Pemerintah Daerah (Penelitian pada SKPD di Kabupaten Labuhan Batu Utara).

Donaldson, L., \& Davis, J. H. (1989). Stewardship Theory or Agency Theory: CEO Governance and Shareholder Returns. Paper Presented at the Annual Meeting of the Academy of Management, Washington, DC.

Fajri, E. Z., \& Senja, R. A. (2008). Kamus Besar Bahasa Indonesia. Jakarta (ID): Difa Publiser.

Fatmawati, E. (2015). Technology Acceptance model (TAM) Untuk Menganalisis Penerimaan Terhadap Sistem Informasi di Perpustakaan file://C:/Users/Acer/Downloads/scholar (8).ris. IQRA: Jurnal IImu Perpustakaan Dan Informasi (e-Journal), 9(1), 1-13.

Fishbein, M., \& Ajzen, I. (1975). Belief, Attitude, Intention and Behavior: AN Introduction to Theory and Research. MA: Addison-Wesley.

Grande, E. U., Estebanez, R. P., \& Colomina, C. M. (2011). The impact of Accounting Information Systems (AIS) on Performance Measures: Empirical Evidence in Spanish SMEs. The International Journal of Digital Accounting Research, 11.

Halim, A. (2014). Manajemen Keuangan Sektor Publik: Problematika Penerimaan dan Pengeluaran Pemerintah. Jakarta: Salemba Empat.

Handayani, S., Kusrini, K., \& Arief, M. R. (2017). Evaluasi Tingkat Penerimaan Sistem Informasi Yudisium Menggunakan Metode TAM. Informasi Interaktif, 2(2), 146-155.

Hargo, U. (2001). Studi Eksplorasi Tentang Penyebaran TI Untuk Usaha Kecil dan Menengah. Jurnal Ekonomi Dan Bisnis Indonesia, 16(2), 153-163.

Hartono, J. (2005). Analisis dan Desain Sistem Informasi: pendekatan terstruktur teori dan praktek aplikasi bisnis. Yogyakarta: Andi.

Hashmi, K. (2004). Introduction and Implementation of Total Quality Management (TQM).

Inpres Nomor 3 Tahun. Tentang Kebijakan dan Strategi Nasional Pengembangan EGovernment. , (2003).

Irawan, B. (2017). Studi Analisis Konsep E-Government: Sebuah Paradigma Baru dalam Pelayanan Publik. Jurnal Paradigma (JP), 2(1), 174-201.

Jogiyanto, H. M. (2004). Analisis dan Desain Sistem Informasi (Edisi Kedu). Yogyakarta.

Kamal, B., \& Noermansyah, A. L. (2010). Analisis faktor yang mempengaruhi implemetasi simda dan kualitas laporan keuangan pada skpd.

Lee, Y. W., \& Strong, D. M. (2003). Knowing-Why About Data Processes and Data Quality. Journal of Management Information Systems, 13-39.

Mc. Leod, R., \& Schell, G. P. (2007). anagement Information Systems (Tenth Edit). Upper Saddle River New jersey 07458: Pearson/Prentice Hall.

Mosley, M. (2008). The DAMA dictionary of data management. Technics Publications, LLC.

Noviarni, E. (2014). Analisis Adopsi Layanan Internet Banking Oleh Nasabah Perbankan Di Pekanbaru (Technology Acceptance Model). Jurnal Al-lqtishad, 1(10).

Peraturan Menteri Dalam Negeri Nomor 13 Tahun 2006. Tentang Pedoman Pengelolaan Keuangan Daerah.

Peraturan Pemerintah Nomor 56 Tahun. Tentang Sistem Informasi Keuangan Daerah. , (2005).

Peraturan Pemerintah Nomor 58 Tahun. Tentang Pengelolaan Keuangan Daerah. , (2005).

Peraturan Pemerintah Nomor 71 Tahun 2010. (n.d.). Tentang Standar Akuntansi Pemerintahan.

Rahayu, S. K. (2012). The Factors That Support The Implementation of Accounting Information System: A Survey in Bandung and Jakarta's Taxpayer Offices. Journal of Global Management. 
Salehi, Mahdi, Rostami, Vahab, \& Abdolkarim, M. (2010). Usefulness of Accounting Information System in Emerging Economy: Empirical Evidence of Iran. International Journal of Economics and Finance, 2(2).

Setiawati, D. (2015). Analisis Faktor Pendukung Implementasi SIMDA dan Pengaruhnya. Terhadap Kualitas Laporan Keuangan Pada SKPD (Penelitian Pada SKPD di Kabupaten Labuhan Batu Utara.

Sunarti, S., \& Nur, I. (1998). Pengaruh Dukungan Manajemen Puncak dan Komunikasi Pemakai-Pengembang terhadap Hubungan Partisipasi dan Kepuasan Pemakai dalam Pengembangan Sistem Informasi. Jurnal Riset Akuntansi Indonesia, 1(2), 193-207.

Supriyanto, E. E. (2016). Kebijakan Inovasi Teknologi Informasi (IT) Melalui Program Elektronik Goverment dalam Meningkatkan Kualitas Pelayanan Publik di Indonesia. JIP (Jurnal IImu Pemerintahan): Kajian IImu Pemerintahan Dan Politik Daerah, 1(1), 141161.

Thong, J. L., Chee-SIng, Y., \& Raman, K. S. (1996). Top Management Support, External Expertise and Information Systems Implementation in Small Businesses. Information Systems Research, 7(2), 248-267.

Undang-Undang Nomor 23 Tahun 2014. Tentang Pemerintah Daerah.

Wibisono, A. F. (2017). Efektifitas Peran BPKP dalam Pembinaan dan Pengawasan Implementasi Sistem Informasi Manajemen Daerah (SIMDA). Jurnal Reviu Akuntansi Dan Keuangan, 7(1), 951-962.

$\mathrm{Xu}, \mathrm{H}$. (2003). Critical Success Factors for Accounting Information Systems Data Quality. University of Southern Queensland. 